\title{
Expression of Glutamate Receptor Genes in the Mammalian Retina: The Localization of GluR1 through GluR7 mRNAs
}

\author{
Dânia E. Hamassaki-Britto, ${ }^{1}$ Irm Hermans-Borgmeyer, ${ }^{2, a}$ Stephen Heinemann, ${ }^{2}$ and Thomas E. Hughes ${ }^{1}$ \\ 'Department of Neurosciences, University of California at San Diego, La Jolla, California 92093-0608 and ${ }^{2}$ Molecular \\ Neurobiology Laboratory, The Salk Institute for Biological Studies, La Jolla, California 92037
}

\begin{abstract}
Seven distinct CDNAs encoding functional subunits of the AMPA/kainate-type glutamate receptors have been recently cloned. This in situ hybridization study was done to determine which subunits are expressed in the retina and, where possible, which neurons express them. Hybridization of ${ }^{35}$ S-UTP-labeled cRNA probes with transverse sections revealed that mRNAs for all seven receptor subunits (GluR1GluR7) are expressed in both cat and rat retinas. GluR1 and GluR2 produced labeling over the entire inner nuclear layer (INL) and ganglion cell layer (GCL). GluR3-GluR7 have more limited distributions, indicative of expression by only a subset of neurons. All of the subunits are expressed by the cells at the inner edge of the INL, where amacrine cells reside, yet the layers with the horizontal, bipolar, and ganglion cells contain different subsets of subunits. These findings suggest that these glutamate receptor subunits are employed at many of the retinal synapses, including the photoreceptor input to the outer plexiform layer and the bipolar cell's contacts with the processes at the INL. It is also possible that some glial cells in the INL express some of the subunits.

Since different combinations of GluR1-GluR3 have been shown to play an important role in the calcium permeability in response to glutamate, we investigated whether single cells coexpressed those subunits. By hybridizing adjacent semithin $(1 \mu \mathrm{m})$ sections of the cat retina with probes for GluR1-GluR3, it was possible to observe coexpression of all three subunits, or of pairs of these subunits, in cells within the INL and GCL.
\end{abstract}

[Key words: excitatory amino acid, glutamate, glutamate receptors, in situ hybridization, receptor subunits, retina]

Many of the excitatory synapses in the mammalian retina are thought to use glutamate, or a related excitatory amino acid, as their neurotransmitter. There is evidence that the photoreceptors, located in the outermost layer of the neural retina, use

\footnotetext{
Received Apr. 21, 1992; revised Oct. 26, 1992; accepted Nov. 10, 1992.

We thank U. Borgmeyer, J. Boulter, B. Bettler, G. Pechl, and J. Egebjerg for providing the cDNAs. Thanks are also due to $R$. Duvoisin and $L$. Britto for critically reading the manuscript and $H$. Karten for his generous assistance and support. This work was supported by grants from NEI (EY08362 to T.E.H.) Muscular Dystrophy Association, the Fritz B. Burns Foundation, and the Human Frontiers Science Program Organization (S.H.). I.H.-B. was the recipient of a fellowship from HFSPO. D.E.H.-B. was the recipient of fellowships from FAPESP and $\mathrm{CNPq}$ (Brazil) in different phases of the project.

Correspondence should be addressed to Dånia E. Hamassaki-Britto, Department of Physiology and Biophysics/ICB, University of São Paulo (USP), 05508 São Paulo SP, Brazil.

Present address: Zentrum für Molekulare Neurobiologie der Universität Hamburg, UKE, Universität Hamburg, 2000 Hamburg 20, Germany.

Copyright (C) 1993 Society for Neuroscience $0270-6474 / 93 / 131888-11 \$ 05.00 / 0$
}

glutamate at their synaptic contacts with horizontal and bipolar cells, whose cell bodies lie in the outer and middle third of the inner nuclear layer (INL), respectively. The bipolar cells are thought to relay their signal to the inner plexiform layer via the release of glutamate (reviewed by Massey, 1990). The postsynaptic targets of the bipolar cells are the ganglion cells, whose cell bodies are located in the ganglion cell layer (GCL), and the amacrine cells, located both at the inner third of the INL and in the GCL. Whereas all of these synapses employ glutamate as their neurotransmitter, there is pharmacological evidence that these synapses differ in terms of the receptors expressed at the postsynaptic surface (reviewed by Monaghan et al., 1989; Massey, 1990). All of the pharmacologically defined glutamate receptor subtypes are used in the retina. These include the metabotropic ACPD (1-amino-cyclopentyl-1,3-dicarboxylic acid) and APB (2-amino-4-phosphonobutyric acid) receptors, which act through second messenger systems, and the glutamate-gated ion channels that respond to KA (kainic acid), AMPA ( $\alpha$-amino3-hydroxy-5-methyl-isoxazole-4-propionic acid), or NMDA ( $N$-methyl-D-aspartic acid).

As the tools of molecular biology have been used to identify and characterize the proteins that make up the neurotransmitter receptors, an important insight has emerged. For each pharmacologically defined receptor there appear to be many different subtypes that differ subtly in their sequence and function. This has been the case for the nicotinic $\mathrm{ACh}$ and the $\mathrm{GABA}_{\mathrm{A}}$ receptors found in the brain (reviewed by Olsen and Tobin, 1990; Schofield et al., 1990; Deneris et al., 1991). This diversity of receptors also appears to be true for the glutamate receptors. In the last few years a number of cDNAs have been isolated from the rat brain that encode functional glutamate receptors. The first cDNA isolated (GluR1; Hollmann et al., 1989) and the subsequent cDNAs corresponding to GluR2, GluR3, and GluR4 are highly similar in structure and function (Boulter et al., 1990; Keinänen et al., 1990; Nakanishi et al., 1990). The expression of each of these cDNAs in Xenopus oocytes or transfected mammalian cells produces a glutamate-gated ion channel with AMPA-like pharmacology. Three additional subunits that are only distantly related to GluR1-GluR4, but that share a high degree of similarity themselves, were subsequently isolated (GluR5, Bettler et al., 1990; GluR6, Egebjerg et al., 1991; GluR7, Bettler et al., 1992). Of these, GluR6 and GluR7 exhibit some characteristics of moderate-affinity KA-binding sites (Bettler et al., 1992).

It is thought that in the brain these receptor subunits are combined to form heteroligomeric receptor complexes. Nothing is known, however, about which sets of subunits are actually combined in vivo. Hollmann et al. (1991) have demonstrated that the expression of GluR I or GluR3 in Xenopus oocytes 
produces a glutamate-gated ion channel that fluxes both monovalent ions and calcium, while the coexpression of GluR 1 or GluR3 with GluR2 creates a receptor complex with little calcium flux. The question has now become to what extent these three subunits are coexpressed by the different neurons in the CNS.

To understand the true diversity of glutamate circuitry in the retina, it will be necessary to identify the different kinds of glutamate receptors used by retinal neurons. For the AMPA/ KA-type receptors, this will involve determining which sets of subunits are expressed by each cell type in the retina. In a previous study, Hughes et al. (1992) used in situ hybridization to localize the mRNAs encoding GluR1-GluR5 in the rat retina. It appears that each of these subunits are used in the retina and that there are some differences in their patterns of distribution. In the present study, we sought to extend these observations by comparing the patterns of distribution of GluR 1-GluR7 in both the rat and cat retinas. In addition, given the importance of calcium flux through a ligand-gated ion channel, we undertook an analysis of serial sections through single cells to determine whether GluR 1 - GluR3 are coexpressed by single retinal neurons.

\section{Materials and Methods}

The retinas of Sprague-Dawley rats and adult cats were used in this study. The rats were given a lethal intraperitoneal injection of sodium pentobarbital and perfused transcardially with $50 \mathrm{ml}$ of salinc followed by $500 \mathrm{ml}$ of $4 \%$ paraformaldehyde (PFA) in phosphate-buffered saline (PBS; $\mathrm{pH} 7.4,0.1 \mathrm{M})$. The eyes were then removed, the anterior poles were cut off, and the vitreous was dissected free. The eyecups were postfixed in 4\% PFA for $2 \mathrm{hr}$. The cats were killed with a lethal dose of sodium pentobarbital, and following death their eyes were quickly removed. The anterior poles of the eyes were then cut away, the vitreous was dissected free, and the eyecup was fixed by immersion in 4\% PFA in PBS for 12-24 hr. Following fixation, both the cat and the rat retinas were cryoprotected by immersion in 30\% sucrose in PBS for 12-24 hr.

To obtain $10-\mu \mathrm{m}$-thick sections, retinas were frozen in embedding medium (O.C.T. compound, Miles Scientific) cut perpendicular to the vitreal surface on a cryostat, and collected on gelatin- and polylysinecoated slides. For semithin sections, small pieces of cat retinas were dehydrated in a graded scrics of cthanol and embedded in diethylene glycol distearate (DGD, Polysciences; Taleporos, 1974; Porrello et al., 1991). Serial $1 \mu \mathrm{m}$ sections were then cut on a diamond knife and collected on gelatin- and polylysine-coated slides.

The protocol used for the hybridization has been described by Hughes et al. (1992). Because all probes were derived from rat tissue, for the cat retina the treatment with RNase $A$ and the washes were reduced to 20 min each. For each of the receptor subunits, two different ${ }^{35}$ S-UTPlabeled RNA probes were used. All sections were exposed for the same time with the different probes. The GluR 1-GluR7 RNA probes were constructed as previously described (Egebjerg et al., 1991; Bettler et al., 1992; Hughes et al., 1992). GluR 1-GluR4 have been shown to exist in two versions (flip and flop) with different amino acid sequences in a small region preceding the predicted fourth transmembrane region (Sommer et al., 1990). Two splice variants have also bcen described for GluR5 (GluR5-1 and GluR5-2, Bettler et al., 1990). The probes for GluR 1-GluR5 were constructed to allow hybridization with both forms of each subunit. Sense probes prepared from full-length cDNA clones were used as a control for nonspecific signal.

Following the hybridization, a $3 \mathrm{~d}$ exposure on Hyperfilm Betamax (Amersham) was used to determine whether the hybridization had worked. The slides were then dipped in NTB-2 nuclear emulsion (Kodak) diluted with water (1:1), stored in the dark for 3-4 weeks, and subsequently developed in D-19 (Kodak) and fixed. The sections were then covered with a mounting medium (mixture of glycerin and PBS, 9:1) and coverslips. The exposed silver grains were observed with darkfield and differential interference contrast optics. The latter was also used to define the INL and GCL.

To identify the same cell in adjacent semithin scctions, high-magnification photographic montages were created for each section and acetate overlays were used for alignment. The density of grains was used as a qualitative index of cellular labeling: only the cells with a density of grains at least five times higher than the background were considered positive for a determined probe.

\section{Results}

Our findings represent a qualitative analysis of the expression of the glutamate receptor subunits GluR 1-GluR7 in the cat and rat retinas. Only the cells with hybridization signal well above the background were considered positive, and we used two different controls to determine the specificity of the labeling. First, no labeling above the background was detected when sense probes were used. Second, two different probes were used for each of the subunits. In each case, the labeling obtained with both probes was very similar.

The localization of receptor subunit mRNAs in rat and cat retinas

In situ hybridization with all of the probcs coding for the glutamate receptor subunits produced specific patterns of labeling over the cat and rat retinas (Fig. 1). The probes produced a strong labeling over the cell bodies in the INL and GCL. There was no detectable labeling over the inner and outer plexiform layers. While the patterns of labeling were similar from probe to probe and between species, there were some subtle differences that are described below.

\section{GluR1 and GluR2}

The distributions of the messages for GluR1 and GluR2 were very similar, although the intensity of the hybridization signal differed between them. For both subunits there was labeling over almost all of the cell bodies in the INL as well as labeling over patches of cells within the GCL. The probes for GluR2 always produced a much stronger hybridization signal than the probes for GluR 1. In the INL of the cat retina, the labeling for GluR 1 appeared to be slightly stronger at the inner edge of the layer, whereas in the rat retina the labeling appeared to be uniformly spread over the entire layer.

\section{GluR3 and GluR4}

The distribution of GluR3 and GluR4 transcripts was more restricted than the GluR 1 and GluR 2 messages. In addition, the patterns of labeling differed both between subunits and between the two different species. In the cat retina, the probes for GluR3 produced labeling over patches of cells in the GCL, over the inner and perhaps medium third of the INL, and over discrete large cells at the outermost edge of the INL. In the rat, the labeling was largely restricted to the GCL and the innermost third of the INL, although a few weakly labeled cells could also be seen in the outer third of the INL. The large positive cells at the outer edge of the rat and cat INL appear to be horizontal cells (Fig. 2).

The GluR4 labeling in the rat was very similar to the pattern observed with GluR3 in the cat retina, particularly the labeling over cells at the outermost edge of the INL (Fig. 2). In the cat, the GluR4 labeling was a diffuse labeling spread across the entire INL, although more concentrated in the innermost part of the INL and over many cells in the GCL. Similar to the GluR3 labeling in the rat retina, only a few labeled cells were seen in the outermost edge of the INL. 


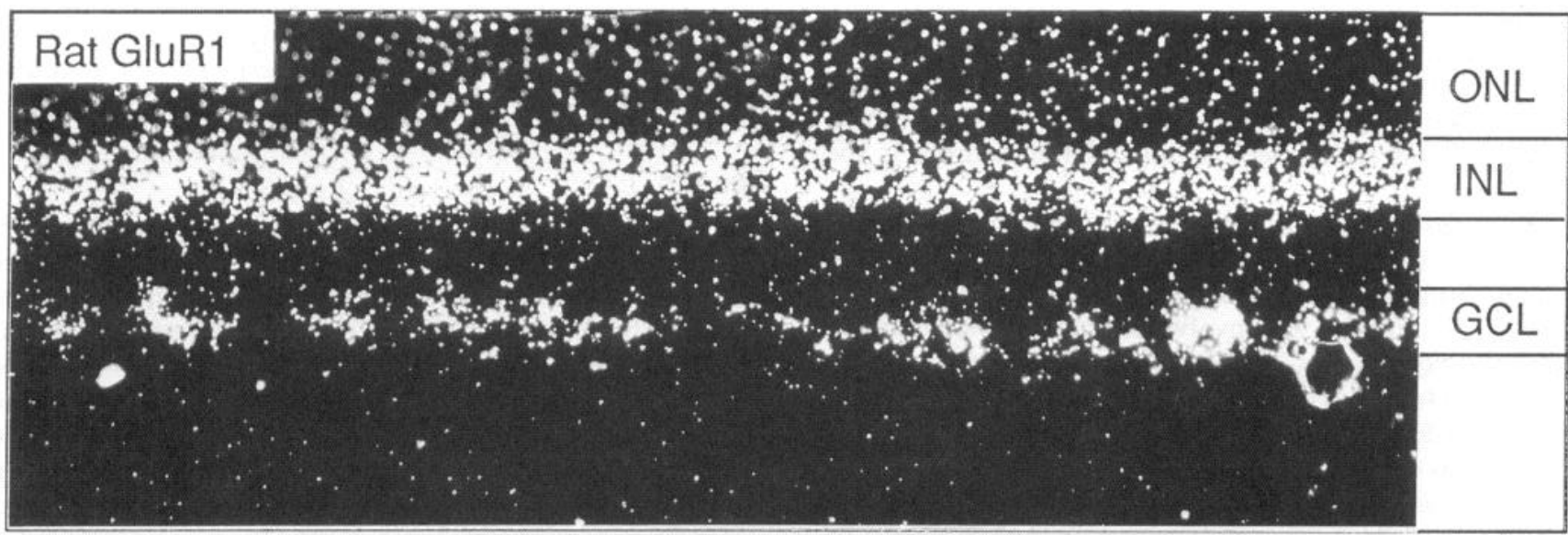

\section{Rat GluR2}

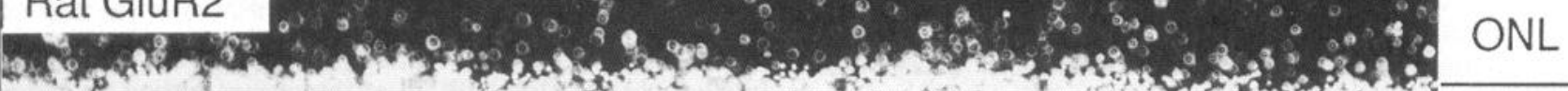
Af.

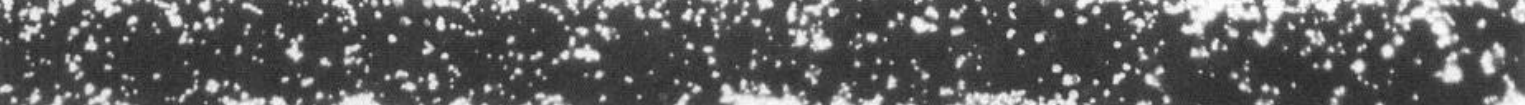

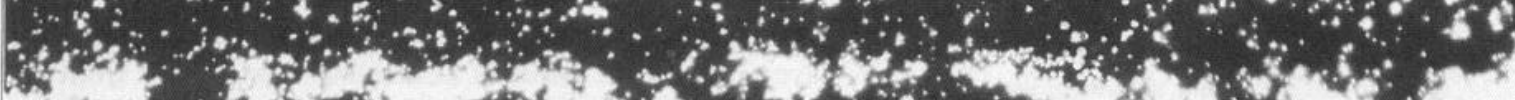

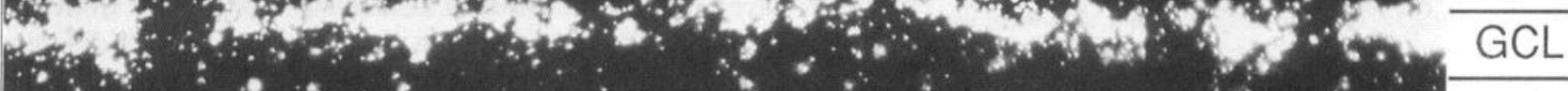

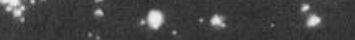

\section{Rat GluR3}

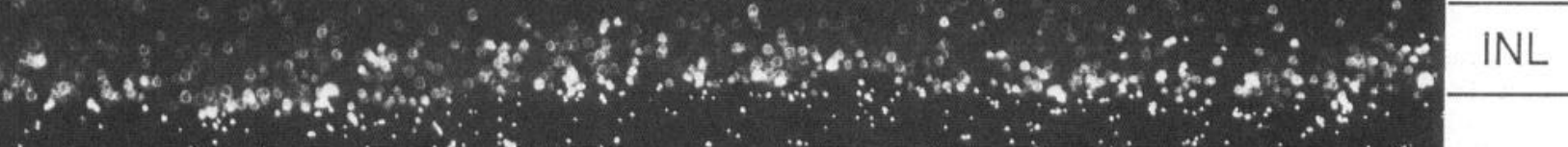

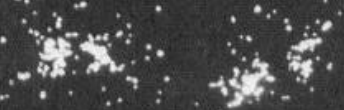

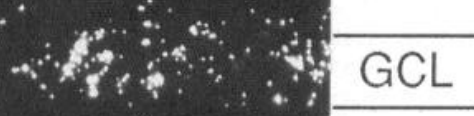
$\cdots$

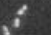
Rat GluR4

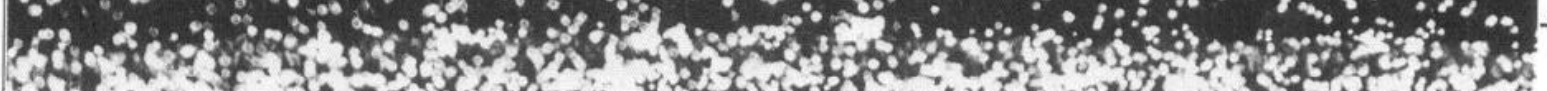

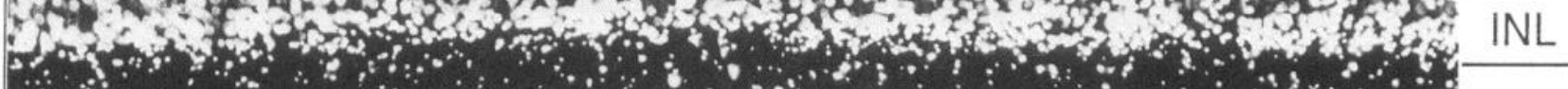

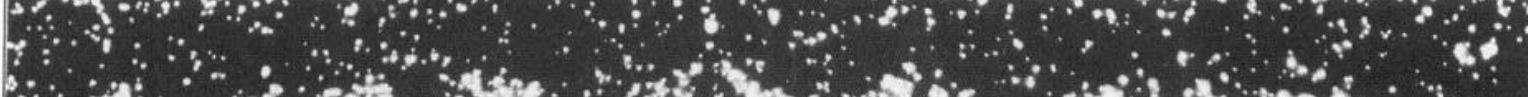
a 

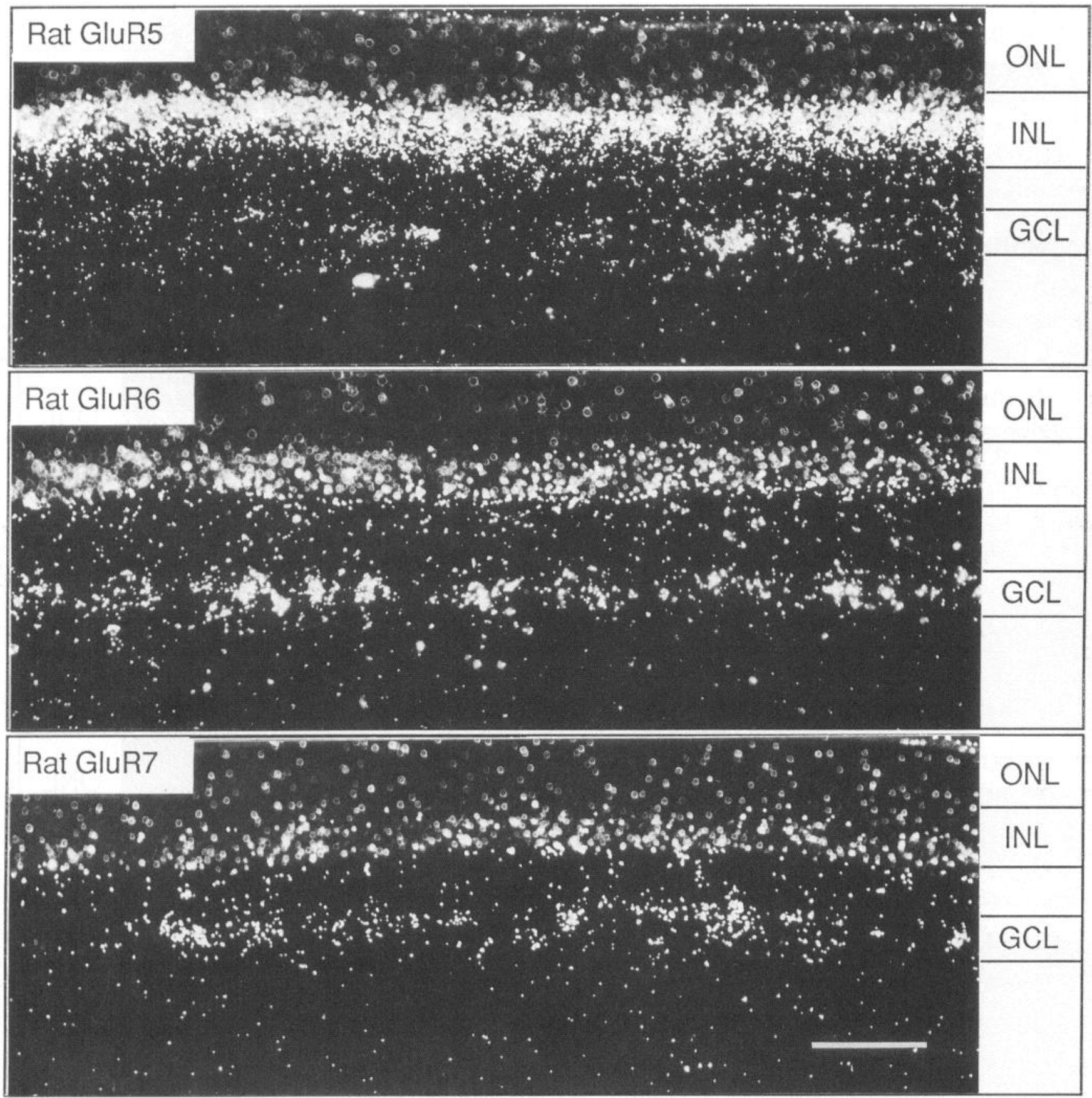

Figure 1. Continued.

\section{GluR5}

In the rat retina, the probes for GluR5 produced a scattered labeling over rare somata in the GCL and produced a strong labeling over cells in the outer two-thirds of the INL. The GluR5 pattern in the cat retina was similar, although the labeling in the INL was more diffuse. The expression of GluR5 differed from the other subunits in that it was concentrated in patches over the middle and outer thirds of the INL. Although a weak hybridization signal was seen over the whole INL, the labeling

Figure 1. Photomicrographs of GluR 1-GluR7 mRNA distribution in transverse sections of cat and rat retinas under dark-field optics. In situ hybridization with ${ }^{35} \mathrm{~S}$-UTP-labeled RNA probes provides a view of the laminar distribution of the receptor subunit messages in transverse sections. Each of the probes produced labeling over sections from both cat and rat retinas, and each probe labeled cells in both the INL and GCL. There were, however, subtle differences in the patterns of distribution both between probes and between species. Probes for GluRI and GluR2 produced an even labeling across the INL and GCL of both cat and rat retinas. The GluR3 and GluR4 patterns were more restricted, and at the outer edge of the INL there was only a dense labeling over some of the cell bodies. GluR5 transcripts were concentrated in the outer two-thirds of the INL of the cat and rat, and only a few positive cells were found in the GCL. GluR6 and GluR7 labeling was spread over the entire INL of the cat, but in the rat the labeling was concentrated over the cells at the innermost edge of the INL. $O N L$, outer nuclear layer. Scale bar, $70 \mu \mathrm{m}$. 


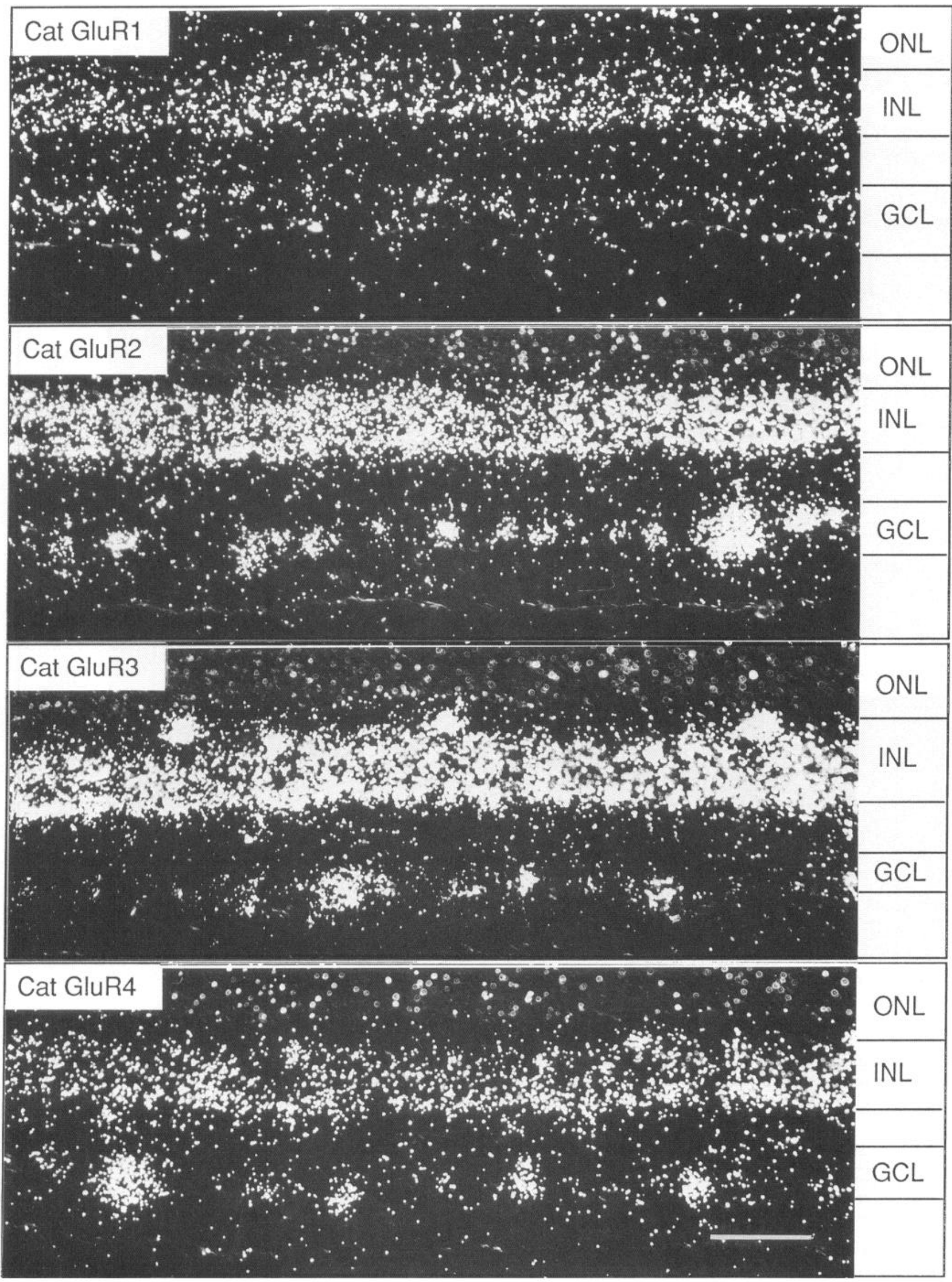

Figure 1. Continued. 

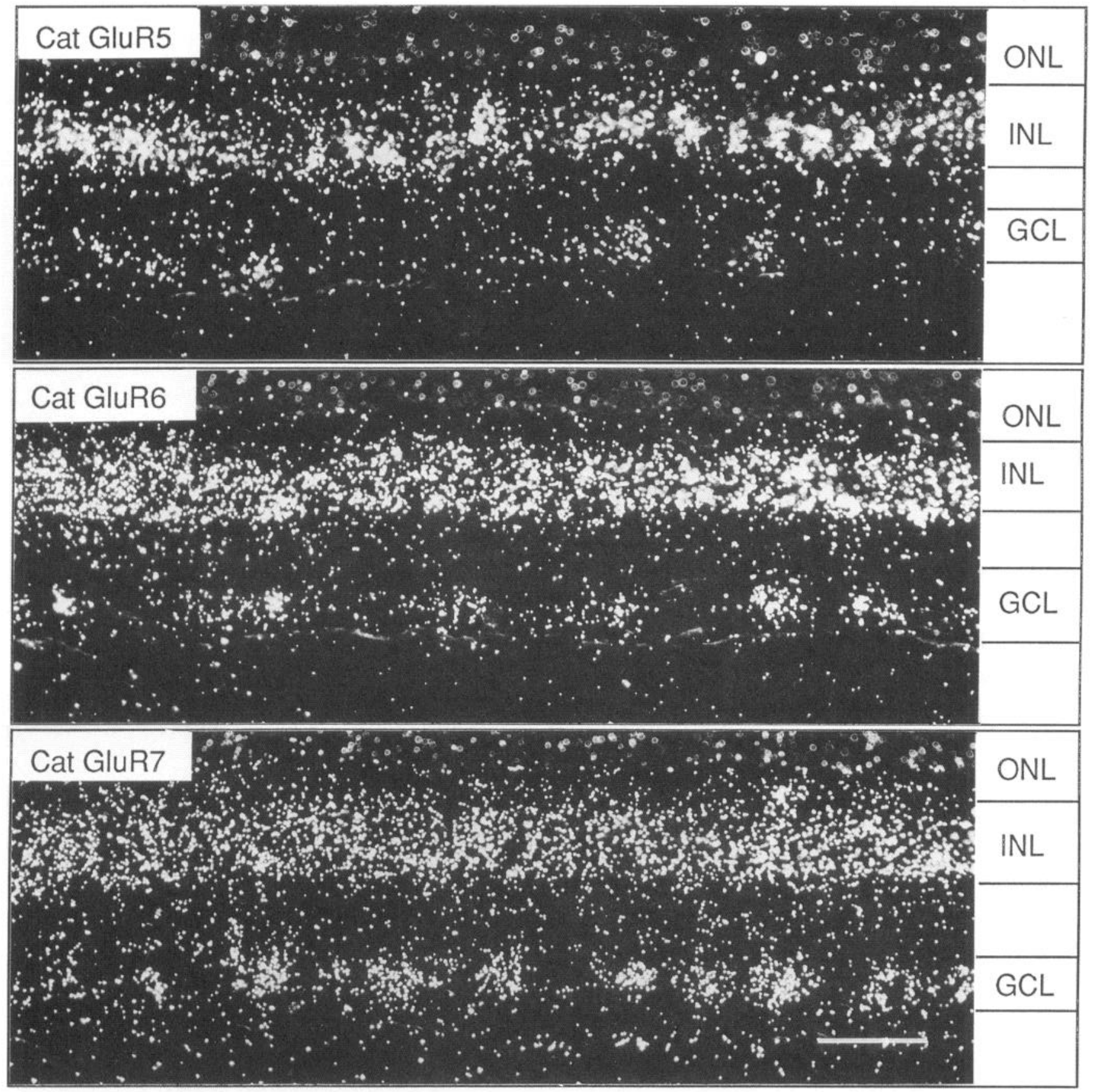

Figure 1. Continued.

over the inner third of this layer was not as evident as described for the other glutamate receptor probes. Only a few dispersed cells in the GCL appeared to be labeled.

\section{GluR6 and GluR7}

GluR6 and GluR7 had a similar distribution in the rat retina. Probes for these subunits produced labeling over cells in the GCL and over the entire INL. The labeling over the INL, however, was not homogeneous; there were concentrated patches of grains over somata at the innermost edge of the layer. In the cat retina, on the other hand, the labeling for both GluR6 and
GluR7 was distributed homogeneously over the INL and in patches over the GCL.

Coexpression of different mRNAs in the cat retina

As expected, the labeling seen over $1-\mu \mathrm{m}$-thick semithin sections was considerably less than that seen over the $10-\mu \mathrm{m}$-thick sections. While it was possible to identify positive cells in these semithin sections, the lower level of signal makes it likely that these results reflect an underestimation of the expression of the glutamate receptor subunits. Another difficulty is that except for some of the large ganglion cells in the GCL, most of the 


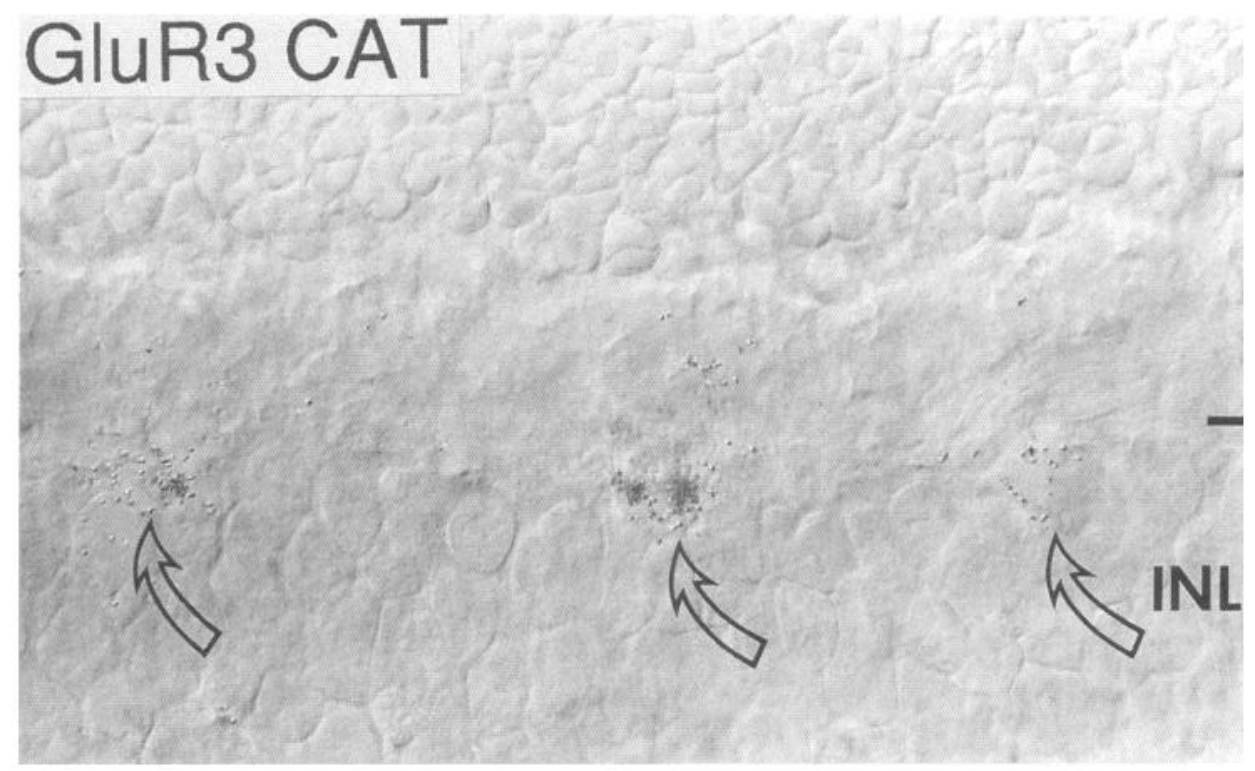

\section{GluR3 RAT}

Figure 2. High-power differential interference contrast photomicrographs of GluR3 and GluR4 mRNA distribution in transverse sections. In the cat retina there were strong patches of GluR3 labeling over cell bodies at the outermost edge of the INL. These appeared to be horizontal cells (top, arrows). Unlike the cat, GluR3 labeling in the outermost portion of the rat INL was very rare (middle, arrow). It was GluR4 probes that produced a strong labeling of what appeared to be the rat's horizontal cells (bottom, arrows). Scale bar, $20 \mu \mathrm{m}$.

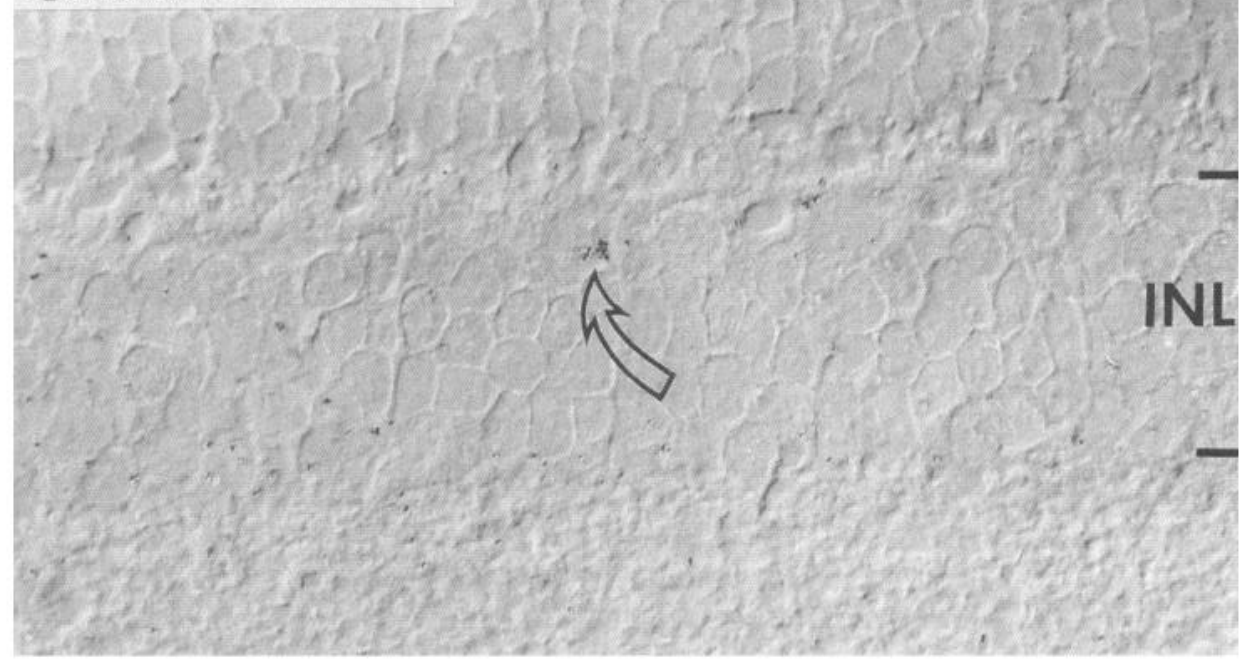

\section{GluR4 RAT}

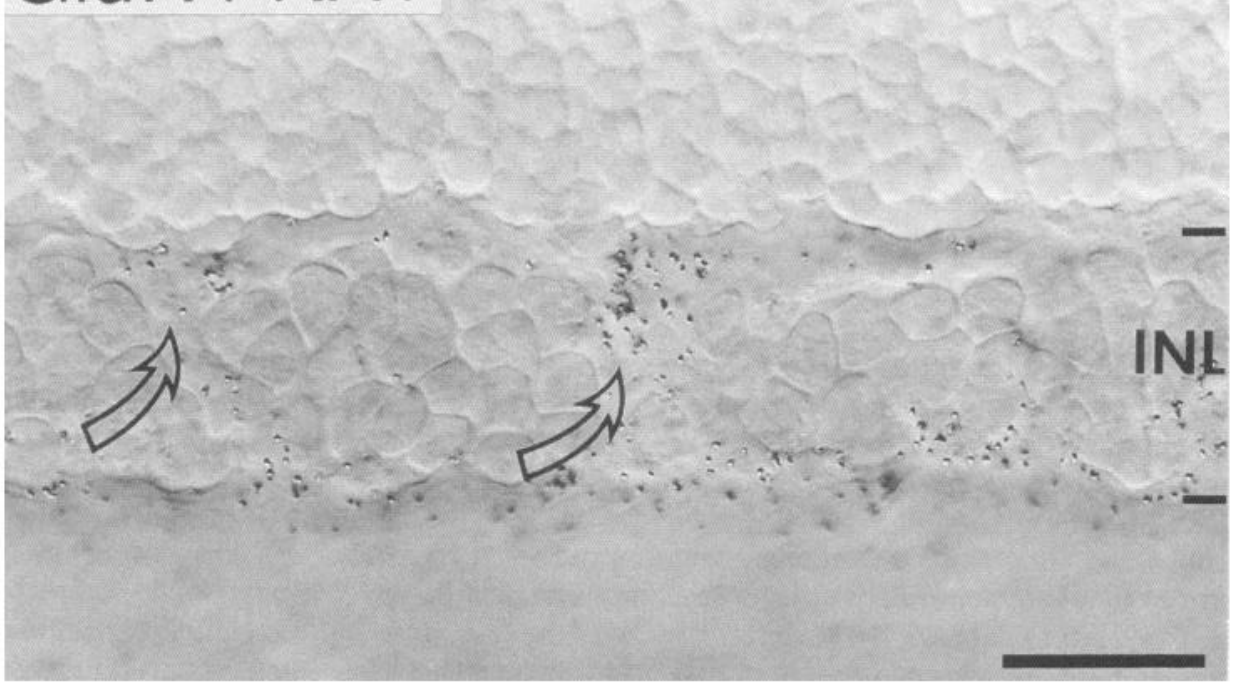


retinal cells could be followed and recognized with certainty for no more than three sequential sections. Again, this means that these results are likely to underestimate the degree of coexpression of the different glutamate receptor genes.

In the GCL it was particularly easy to follow the large ganglion cells from section to section. Figure 3 shows one ganglion cell that is $30 \mu \mathrm{m}$ in its largest diameter and resembles an $\alpha$-ganglion cell (Wässle and Boycott, 1991). A signal above background could be seen over it with probes against GluR1, GluR2, and GluR3. Similarly, smaller cells of the GCL appeared to coexpress these three subunits. Twenty-seven cells showed coexpression of GluR 1-GluR3 or of different pairwise combinations. GluR2 was always one of the subunits expressed by the cells in the GCL in which coexpression was observed (GluR1-GluR3 = 12; GluR1 and GluR2 = 8; GluR2 and GluR3 = 7; GluR1 and GluR3 = 0).

In the INL, it was more difficult, though possible, (Fig. 4) to identify cells that expressed multiple glutamate receptor subunits. The small size of the cell bodies in the INL made it difficult to identify the same somata in adjacent sections, and the tight packing of the cell bodies and spread of exposed silver grains made it difficult to determine with certainty which cells were labeled. Nevertheless, it was possible to identify 41 cells in this material that appeared to contain transcripts of GluR1-GluR3 $(n=4)$ or of different pairwise combinations (GluR1 and GluR3 = 4; GluR2 and GluR3 = 26; GluR 1 and GluR2 = 7). Only a small number of these cells did not have message for GluR2 ( $n$ $=4$ ). These colocalization data included cells that were located either at the outermost part of the INL or at the innermost part of the INL, where the horizontal cells and the amacrine cells reside, respectively. We were unable to characterize any type of colocalization for the cells located in the middle part of the INL.

\section{Discussion}

Molecular biology has recently provided new insights into the diversity of the ligand-gated ion channels. Counting splice variants, there are at least 12 different ligand-gated AMPA/KAtype glutamate receptor subunits expressed in the brain (Hollmann et al., 1989; Bettler et al., 1990, 1992; Boulter et al., 1990; Keinänen et al., 1990; Nakanishi et al., 1990; Sommer et al., 1990; Egebjerg et al., 1991). If we assume that the protein products of these different genes are subunits combined to form heteroligomeric receptor complexes, then a tremendous number of possible receptor complex subtypes becomes theoretically possible. The problem that now presents itself is how these different receptor subunits are actually used by the nervous system. In the retina, the first-order questions are (1) are the glutamate receptor subunits isolated from brain also expressed in the retina or are there still other subunits that are used in the retina; (2) if the glutamate receptor subunits are used in the retina, are they all expressed by the same cell types or is there differential expression; and (3) to what extent are multiple subunits expressed by the same cell?

The central finding of this study is that all of the cloned glutamate receptors GluR1-GluR7 are expressed in both the

Figure 3. Serial semithin sections of cat retina $(1 \mu \mathrm{m})$ processed for detection of GluR 1-GluR3 messages. The photomicrographs illustrate a large ganglion cell, likely an $\alpha$-ganglion cell, that appears to contain message for each of the three subunits in the GCL (arrows). IPL, inner plexiform layer. Scale bar, $25 \mu \mathrm{m}$.
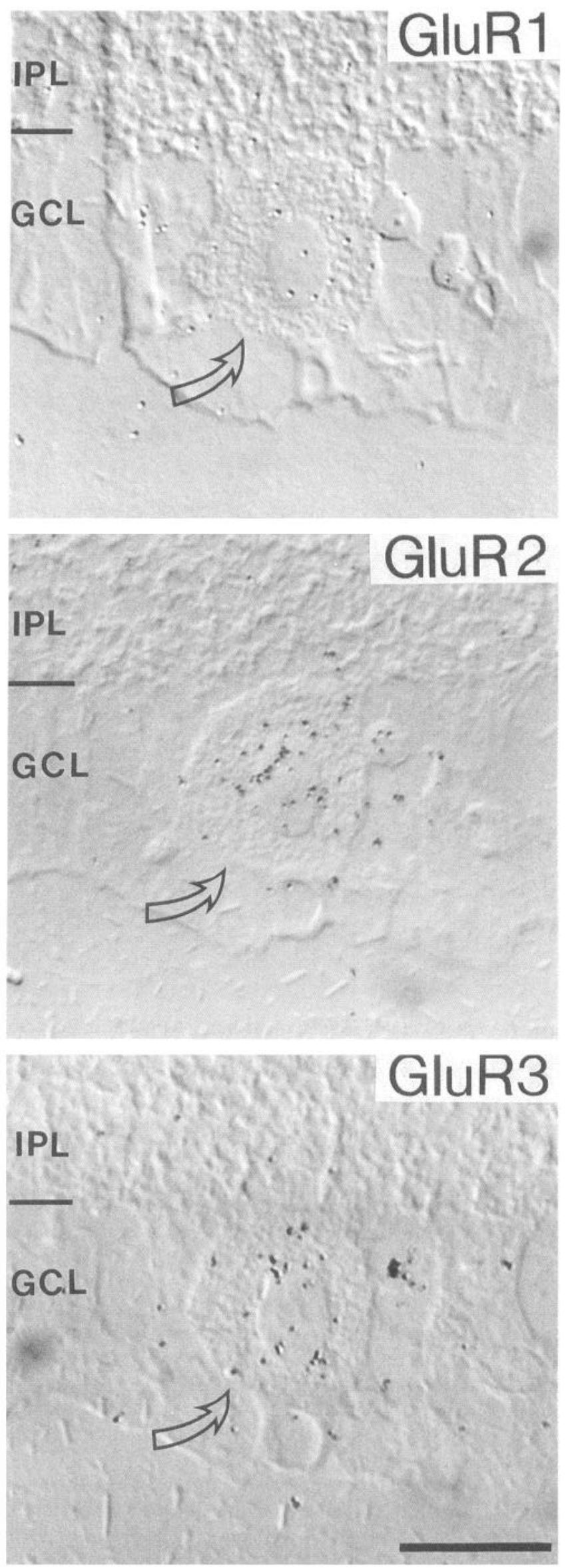

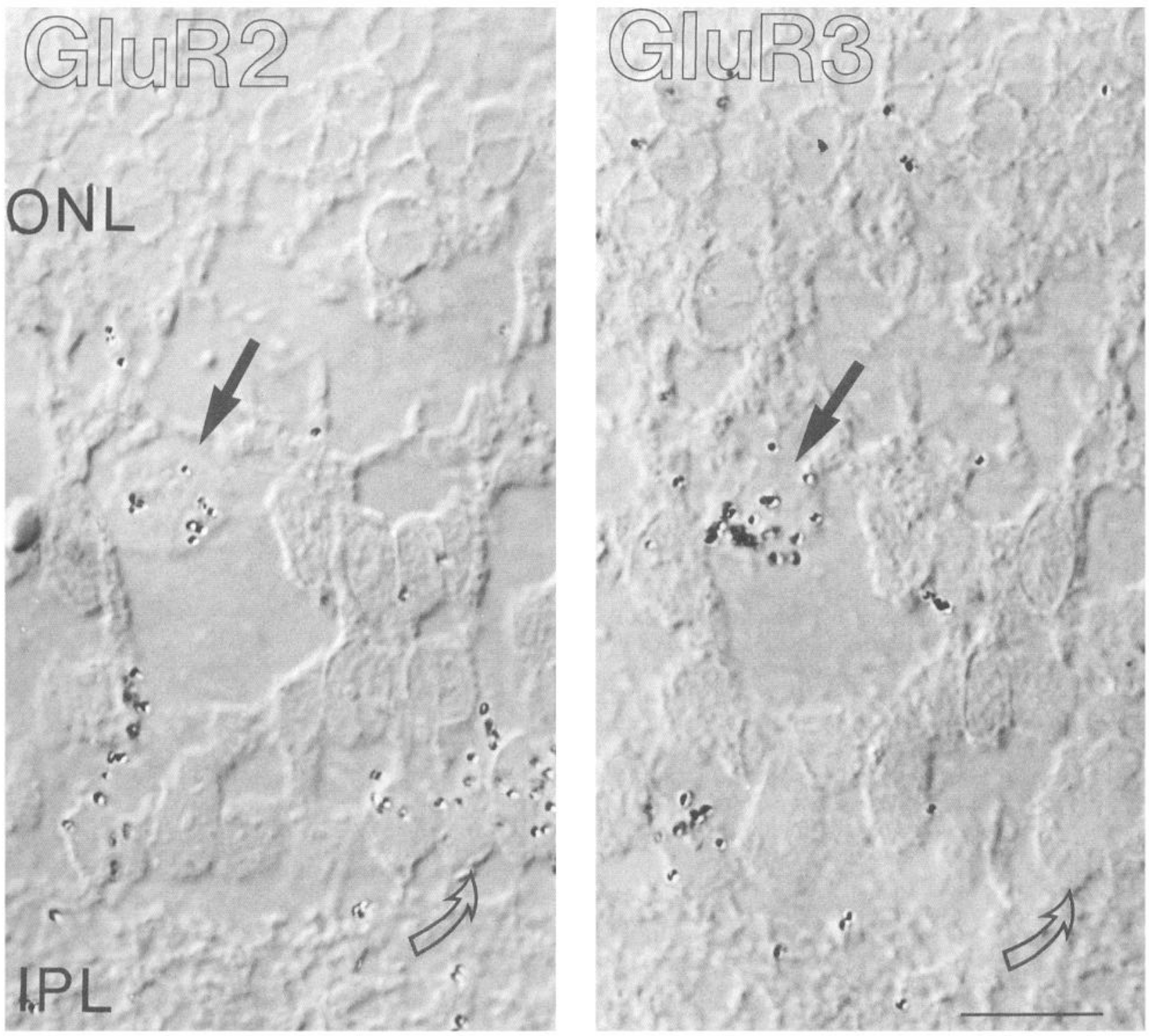

Figure 4. Serial semithin sections of cat retina $(1 \mu \mathrm{m})$ illustrating coexpression of GluR2 and GluR 3 in presumptive horizontal cells at the outermost edge of the INL (solid arrows). A group of putative amacrine cells expressing GluR2 but not GluR3 is also observed at the innermost edge of the INL (open arrows). IPL, inner plexiform layer; $O N L$, outer nuclear layer. Scale bar, $10 \mu \mathrm{m}$.

cat and rat retina. It seems likely that the protein products of these genes are directly involved in the glutamate circuitry of the retina. Except for GluR5, where the pharmacology is unclear, the glutamate receptors GluR1-GluR7 have an AMPA/KA (GluR1-GluR4) or KA (GluR6 and GluR7) pharmacology. These pharmacological classes of receptors are thought to mediate the synaptic transmission between the photoreceptors and the horizontal and bipolar cells as well as the synaptic transmission between the bipolar cells and the amacrine and ganglion cells (reviewed by Massey, 1990). The patterns of distribution for the GluR1-GluR7 mRNAs indicate that these receptor subunits could be involved in all of that synaptic circuitry. Taken together, there is labeling for one or more of the glutamate receptor subunits over the entire INL and the GCL.

This is an important result because it offers a new means to investigate the glutamate system of the retina. In the past, it has only been possible to study the release of glutamate and the receptors for glutamate with the tools of pharmacology and physiology. This neurotransmitter system has been particularly difficult to study anatomically, since the transmitter itself has been hard to localize with confidence because of its ubiquitous use in cellular processes (Marc et al., 1990). The proteins that make up the receptors have been impossible to purify biochemically and study immunocytochemically. The observation that GluR1-GluR7 are expressed in the glutamate circuitry in the retina provides reason to believe that antibodies directed against the protein products of these genes should make it possible in the future to study the location of the actual receptor complexes expressed in the retina.

While the extensive pattern of labeling produced by all of the probes is sufficient to account for the AMPA/KA receptors expressed by the horizontal, bipolar, amacrine, and ganglion cells, several of the subunits appear to have a limited pattern of expression. In both the cat and the rat retinas, GluR3-GluR7 have had a limited distribution, indicating that they are expressed by a subset of the neurons that are thought to express AMPA/KA 
glutamate receptors. In the rat and cat, GluR 3 and GluR4 produced strong labeling over the GCL and over the inner third of the INL, where the amacrine cells reside. Unlike GluR 1 and GluR2, the GluR 3 and GluR4 labeling over the outer two-thirds of the INL was more restricted and appeared to be concentrated over only some of the cell bodies in the outer third of the INL. GluR5 probes produced a strong labeling over the INL of rat and cat but produced only a scant labeling over the cells in the GCL. GluR6 and GluR7 had a restricted pattern of distribution in the rat retina, but in the cat GluR6 and GluR7 exhibited a widespread distribution similar to GluR1.

These restricted and different patterns of expression could indicate that there are specific functions for each of the glutamate receptor subunits. To date, there is a limited body of evidence for subunit-specific circuitry in the retina involving the nicotinic ACh (Hamassaki-Britto et al., 1991; Whiting et al., 1991), GA$\mathrm{BA}_{\mathrm{A}}$ (Hughes et al., 1991), and glycinergic (Pourcho and Owczarzak, 1991) receptors, although the functional explanations for this heterogeneity remain unknown. In the case of the glutamate receptors, the expression of different combinations of the subunits produces receptors that differ in their current/voltage relationships and ion selectivity (Boulter et al., 1990; Hollmann et al., 1991). GluR1, GluR3, and GluR1 plus GluR3 channels have an AMPA-like pharmacology and, in response to glutamate, flux both sodium and calcium. Such receptors may well exist in the INL since our data indicate that both GluR 1 and GluR3 are expressed there. Electrophysiological studies have demonstrated receptors with these properties in the Off-center bipolar cells of the salamander retina (Gilbertson et al., 1991) and in the horizontal cells of the fish retina (Linn and Christensen, 1992). When GluR1 or GluR3 is combined with GluR2, a glutamate-gated ion channel is produced with little or no calcium flux (Hollmann et al., 1991; Keller et al., 1992). The experiments of colocalization of subunits showed that most of the cells expressing combinations of GluR1 or GluR3 subunits expressed GluR2 as well. Thus, if the GluR1 and/or GluR3 plus GluR2 mRNA detected in single cells in the INL and in the GCL are translated into proteins, then the prediction would be that such cells will express a glutamate receptor with little calcium permeability. Considering also that GluR2 is extensively distributed in the retina, it is likely that the majority of cells in the retina have AMPA/KA receptors with little calcium permeability in response to glutamate.

This difference in the ion selectivity of the glutamate receptor channels contributes to the functional diversity of these receptors and probably has an important role. For instance, at synapses with a glutamate receptor permeable to calcium, the transmitter may have both an immediate effect upon the cell's membrane potential as well as a long-term effect through an increased intracellular concentration of calcium. The regulation of this calcium flux at the channel appears to be due to a single amino acid in the putative second transmembrane domain (Hume et al., 1991; Verdoorn et al., 1991), and is controlled by a posttranscriptional process (Sommer et al., 1991). This control of the calcium permeability in AMPA/KA receptors may be important for the establishment of excitatory circuits in the developing nervous system similar to that observed for the NMDA receptors (Kleinschmidt et al., 1987).

The pattern of subunit distribution differed both between the subunits and, for some subunits, between rat and cat. For example, in the cat retina there was a strong GluR3 signal over what appear to be the horizontal cells, whereas in the rat retina this signal is so infrequent that it was not detected in previous experiments (Hughes et al., 1992). Species differences occur in the distribution of GluR4, GluR6, and GluR7 as well. There are at least two explanations for these differences between rat and cat. First, it is possible that distinct labeling patterns are reflections of differences in the relative abundance of particular cell types. For instance, there is evidence indicating that only one type of horizontal cell, the axon-bearing B-type, is present in the rat retina (L. Peichl, personal communication). Thus, it is possible that GluR3 is expressed exclusively by the other type of horizontal cell, the A-type, which is present in the cat retina but not in the rat retina. Second, the possibility exists that there is a difference between species in terms of which subunits a particular cell type expresses.

Whereas the pattern of labeling indicates that each of the receptor subunits is expressed by some of the major types of retinal neurons, it does not rule out the expression by less frequent cell types such as the interplexiform cells or the displaced ganglion cells located in the inner third of the INL. The possibility also exists that glial cells express some of the glutamate receptor mRNAs. Indeed, most glial cells appear to express one or more types of ligand-gated channels (reviewed by Barres, 1991). In the retina, the cell bodies of the Müller cells reside in the middle of the INL interspersed between the cell bodies of the bipolar cells. Since each of the probes produced some labeling in the INL, it is possible that all or a few of the glutamate receptor genes are expressed by these glial cells. In culture, type II astrocytes express glutamate receptors and contain mRNAs encoding GluR1 (J. Boulter, personal communication). An equally plausible explanation, however, is that all of the labeling is due to positive bipolar cells. Hughes et al. (1992) have shown that the rod bipolar cell is responsible for at least some of the GluR2 signal produced over the INL of the rat retina.

Whereas the results of the present study provide some insight into the organization of the glutamate system of the retina, it seems certain that they represent only a partial glimpse of the total system. Alternative splice variants have been described for GluR 1-GluR5, and it remains to be determined whether all of them are expressed in the retina (Bettler et al., 1990; Sommer et al., 1990). Moreover, there is evidence that the retina uses the APB receptor at the photoreceptor-On-center bipolar cell synapse (reviewed by Miller and Slaughter, 1986). This receptor remains to be cloned and characterized. Similarly, there is evidence that the NMDA and ACPD receptors are used in the inner plexiform layer (reviewed by Massey, 1990), yet they remain to be studied (the first members of each of these receptors were cloned during the preparation of this article; Houamed el al., 1991; Masu et al., 1991; Moriyoshi et al., 1991; Tanabe et al., 1992).

A fundamental limitation of the technique employed here is that it involves the localization of mRNA and not of the protein itself. Indeed, for each of the subunits the labeling was confined to the cell bodies, suggesting that the message is located there. To obtain a view of how these receptors are used in the retina, it will be necessary to study the location of the receptor proteins. Thus, the next step toward understanding the subunit composition of the glutamate synapses in the retina will require specific antibodies.

In summary, recent advances in molecular biology have made it possible to clone and characterize at least some of the AMPA/ KA-type glutamate receptors. This has revealed an unforeseen diversity of receptor subunits. The present findings indicate that 
all of these receptor subunits are used in the glutamate neurotransmission within the retina. It seems likely that an understanding of the ways in which these receptor proteins are expressed and combined will provide us with fundamental insights into the excitatory circuitry of the mammalian retina.

\section{References}

Barres BA (1991) New roles for glia. J Neurosci 11:3685-3694.

Bettler B, Boulter J, Hermans-Borgmeyer I, O'Shea-Greenfield A, Deneris ES, Moll C, Borgmeyer U, Hollmann M, Heinemann S (1990) Cloning of a novel glutamate receptor subunit GluR5: expression in the nervous system during development. Neuron 5:583-595.

Bettler B, Egebjerg J, Sharma G, Pecht G, Hermans-Borgmeyer I, Moll $C$, Stevens CF, Heinemann S (1992) Cloning of a putative glutamate receptor: a low-affinity kainate-binding subunit. Neuron 8:257-265.

Boulter J, Hollmann M, O'Shea-Greenfield A, Hartley M, Deneris E, Maron C, Heinemann S (1990) Molecular cloning and functional expression of glutamate receptor subunit genes. Science 249:10331037.

Deneris ES, Connolly J, Duvoisin R, Rogers SW (1991) Pharmacological and functional diversity of neuronal nicotinic acetylcholine receptors. Trends Pharmacol 12:34-41.

Egebjerg J, Bettler B, Hermans-Borgmeyer I, Heinemann S (1991) Cloning of a cDNA for a glutamate receptor subunit activated by kainate but not AMPA. Nature 351:745-748.

Gilbertson TA, Scobey R, Wilson M (1991) Permeation of calcium ions through non-NMDA glutamate channels in retinal bipolar cells. Science 251:1613-1615.

Hamassaki-Britto DE, Britto LRG, Karten HJ, Keyser KT, Lindstrom J (1991) Double-labeling studies of the distribution of alpha-bungarotoxin binding proteins and nicotinic receptors in the chick retina. Soc Neurosci Abstr 17:1565.

Hollmann M, O'Shea-Greenfield A, Rogers S, Heinemann S (1989) Cloning by functional expression of a member of the glutamate receptor family. Nature 342:643-648.

Hollmann M, Hartley M, Heinemann S (1991) Ca2+ permeability of KA-AMPA-gated glutamate receptor channels depends on subunit composition. Science 252:851-853.

Houamed KM, Kuijper JL, Gilbert TL, Haldeman BA, O'Hara PJ, Mulvihill ER, Almers W, Hagen FS (1991) Cloning expression and gene structure of a G-protein-coupled glutamate receptor from rat brain. Science 252:1318-1321.

Hughes TE, Grünert Y, Karten HJ (1991) GABA A receptors in the retina of the cat: an immunohistochemical study of the wholemounts sections and dissociated cells. Vis Neurosci 6:229-238.

Hughes TE, Hermans-Borgmeyer I, Heinemann S (1992) Differential expression of glutamate receptor genes (GluR 1-5) in the rat retina. Vis Neurosci 8:49-55.

Hume RI, Dingledine R, Heinemann SF (1991) Identification of a site in glutamate receptor subunits that controls calcium permeability. Science 253:1028-1031.

Keinänen K, Wisden W, Sommer B, Werner P, Herb A, Verdoorn TA, Sakmann B, Seeburg PH (1990) A family of AMPA-selective glutamate receptors. Science 249:556-560.

Keller BU, Hollmann M, Heinemann S, Konnerth A (1992) Calcium influx through kainate/AMPA receptor channels is regulated by cAMP. EMBO J 11:891-896.

Kleinschmidt A, Bear MF, Singer W (1987) Blockade of NMDA re- ceptors disrupts experience-dependent plasticity of kitten striate cortex. Science 238:355-358.

Linn CP, Christensen BN (1992) Excitatory amino acid regulation of intracellular $\mathrm{Ca}_{2}$ in isolated catfish cone horizontal cells measured under voltage and concentration clamp conditions. J Neurosci 12: 2156-2164

Marc RE, Liu W-LS, Kalloniatis M, Raiguel SF, Van Haesendonck E (1990) Patterns of glutamate immunoreactivity in the goldfish retina. J Neurosci 10:4006-4034.

Massey SC (1990) Cell types using glutamate as a neurotransmitter in the vertebrate retina. In: Progress in retinal research (Osborne $\mathrm{N}$, Chader J, eds), pp 399-425. Oxford: Pergamon.

Masu M, Tanabe Y, Tsuchida K, Shigemoto R, Nakanishi S (1991) Sequence and expression of a metabotropic glutamate receptor. Nature 349:760-765.

Miller RF, Slaughter MM (1986) Excitatory amino acid receptors of the retina: diversity of subtypes and conductance mechanisms. Trends Neurosci 9:211-218.

Monaghan DT, Bridges RJ, Cotman CW (1989) The excitatory amino acid receptors: their classes pharmacology and distinct properties in the function of the central nervous system. Annu Rev Pharmacol Toxicol 29:365-402.

Moriyoshi K, Masu M, Ishii T, Shigemoto R, Mizuno N, Nakanishi S (1991) Molecular cloning and characterization of the rat NMDA receptor. Nature 354:31-37.

Nakanishi N, Schneider NA, Axel R (1990) A family of glutamate receptor genes-evidence for the formation of heteromultimeric receptors with distinct channel properties. Neuron 5:569-581.

Olsen RW, Tobin AJ (1990) Molecular biology of GABA receptors. FASEB J 4:1468-1480.

Porrello K, Bhat SP, Bok D (1991) Detection of interphotoreceptor retinoid binding protein (IRBP) $\mathrm{mRNA}$ in human and cone-dominant squirrel retinas by in situ hybridization. J Histochem Cytochem 39: 171-176.

Pourcho RG, Owczarzak MT (1991) Glycine receptor immunoreactivity is localized at amacrine synapses in cat retina. Vis Neurosci 7:611-618.

Schofield PR, Shivers BD, Seeburg PH (1990) The role of receptor subtype diversity in the CNS. Trends Neurosci 13:8-11.

Sommer B, Keinänen K, Verdoorn TA, Wisden W, Burnashev N, Herb A, Köhler M, Takagi T, Sakmann B, Seeburg PH (1990) Flip and flop: a cell-specific functional switch in glutamate-operated channels of the CNS. Science 249:1580-1585.

Sommer B, Köhler M, Sprengel R, Seeburg PH (1991) RNA editing in brain controls a determinant of ion flow in glutamate-gated channels. Cell 67:11-19.

Taleporos P (1974) Diethylene glycol distearate as an embedding medium for high resolution light microscopy. J Histochem Cytochem 22:29-34.

Tanabe Y, Masu M, Ishii T, Shigemoto R, Nakanishi S (1992) A family of metabotropic glutamate receptors. Neuron 8:169-179.

Verdoorn TA, Burnashev N, Monyer H, Seeburg PS, Sakmann B (1991) Structural determinants of ion flow through recombinant glutamate receptor channels. Science 252:1715-1718.

Wässle H, Boycott BB (1991) Functional architecture of the mammalian retina. Physiol Rev 71:447-480.

Whiting PJ, Schoepfer R, Conroy WG, Gore MJ, Keyser KT, Shimasaki S, Esch F, Lindostrom J (1991) Expression of nicotinic acetylcholine receptor subtypes in brain and retina. Mol Brain Res 10:61-70. 